\title{
Social dumping and the EU integration process
}

Magdalena Bernaciak

Working Paper 2014.06

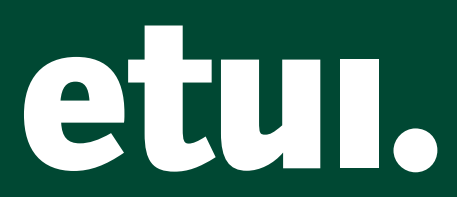




\section{Social dumping and the EU integration process}

Magdalena Bernaciak

Working Paper 2014.06

european trade union institute 
Magdalena Bernaciak is a researcher at the European Trade Union Institute (ETUI) in Brussels. Contact: mbernaciak@etui.org

This paper is based on the introduction to the book Social dumping and market expansion in Europe, edited by Magdalena Bernaciak and forthcoming with Routledge. The paper also presents some of the conclusions of this book which was completed within the framework of the ETUI-based research project 'Social dumping in the enlarged EU: concepts, challenges and policy options'.

Brussels, 2014

๑Publisher: ETUI aisbl, Brussels

All rights reserved

Print: ETUI Printshop, Brussels

D/2014/10.574/24

ISSN 1994-4446 (print version)

ISSN 1994-4454 (pdf version)

The ETUI is financially supported by the European Union. The European Union is not responsible for any use made of the information contained in this publication. 


\section{Contents}

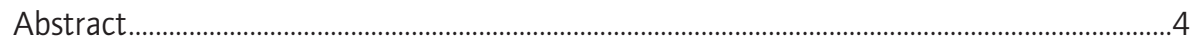

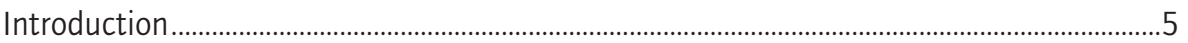

Social dumping in popular and academic discussions .........................................................

Competition and regulation in capitalist markets................................................................... 11

Social constraints and the appeal of social dumping .............................................................. 14

Europe: from social model to social dumping? ......................................................................... 18

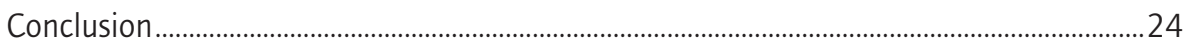

References 


\section{Abstract}

This paper proposes a conceptualization of social dumping and applies it to an analysis of the EU integration process. Building on recent contributions in the fields of economic theory, economic sociology and institutional political economy, it defines social dumping as the practice, undertaken by self-interested market participants, of undermining or evading existing social regulations with the aim of gaining a competitive advantage. The paper also argues that the social dumping practices of market actors are encouraged by policy initiatives of liberalization and deregulation. To illustrate this point, it shows how two major European integration projects - the creation of the Internal Market, and EU enlargement to the east and to the south have made social dumping more pertinent by providing market participants with new strategic opportunities to contest social norms.

\section{Keywords}

Social dumping, marketization, competition, Internal Market, EU enlargement 


\section{Introduction ${ }^{1}$}

'EU governments must end social dumping', argued the European Trade Union Confederation in the course of negotiations for a new EU Directive enforcing the rights of posted workers (ETUC 2013). The business community seems equally concerned about the issue, albeit for a different reason: in its 2012 Annual Report, the European Construction Industry Federation maintained that preventing social dumping was crucial for the preservation of the sector's competitiveness (FIEC 2012). Neither of the organizations, however, provides a definition of social dumping, which is symptomatic for broader trends in Europe: even though the term regularly appears in the public discourse and in policymaking circles, it is usually used in a manner that is convenient for the individual participants, thus opening the door for misconceptions and illgrounded accusations.

In a similar vein, social dumping has so far received limited scholarly attention. It seems that the normative clout and emotional load accompanying the term's popular use has discouraged scholars from addressing the issue in more detail, leaving unclear both the mechanism behind the notion and its relation to socioeconomic changes in Europe - in particular, to the process of EU integration. Despite the vagueness of the term, however, it is still capable of influencing actors' strategies and government policies. The introduction of transition periods temporarily restricting the access of the workforces of candidate countries to the labour markets of the old EU member states, as well as the failure of the French and Dutch EU Constitutional Treaty referenda, can be largely seen as resulting from the presence of real or perceived social dumping concerns within European societies.

In view of the high political resonance of social dumping in Europe, on the one hand, and the term's ambiguity, on the other, there is a need to systematize the concept and to explore the mechanisms underlying social dumping practices. To this end, this paper proposes a conceptualization of social dumping and applies it to an analysis of the EU integration process. Building on recent contributions in the fields of economic theory, economic sociology and institutional political economy, it defines social dumping as the practice, undertaken by self-interested market participants, of undermining or evading existing social regulations with the aim of gaining a competitive advantage.

1. I would like to thank Svetoslav Salkin for his critical remarks and suggestions concerning the paper's main argument, as well as Jens Arnholz, Torben Krings, Ian Greer and Vera Šćepanović for their comments on the earlier versions of the paper. The usual caveats apply. 
It then shows how the two major EU integration projects - the creation of the Internal Market, and EU enlargement to the east and to the south - have provided market actors with new incentives and strategic opportunities to contest or circumvent transnational and national social regulations. The paper argues that in the short run, social dumping exerts downward pressure on wages and working conditions in Europe. If pursued by a large number of actors over a long period of time, however, it could considerably weaken the beneficial social effects of economic growth, threaten social cohesion and even lead to the disintegration of the market order.

The paper is structured as follows. It first critically reviews different uses of the term 'social dumping' in the public discourse and academia. It then brings together the insights of the literature on capitalist competition, marketization and the role of regulation so as to construct the concept of social dumping. The paper subsequently shows how the deregulation and liberalization initiatives that accompanied the creation of the Internal Market and the EU's southern and eastern enlargements have encouraged market participants to pursue social dumping strategies. The concluding section summarizes the argument and outlines the policy implications of the paper's approach to social dumping. 


\section{Social dumping in popular and academic discussions $^{2}$}

Popular debates on social dumping have accompanied various initiatives towards trade liberalization and advances in economic integration between 'high-' and 'low-wage' countries. Cross-national differences in wage levels and extents of social protection, as well as different degrees to which labour market regulations are actually implemented, have often been a source of concern among high-wage country actors about the potential negative consequences of integration processes. The fear is that as the liberalization agenda progresses, differences in social standards could be used by low-wage country actors to gain a higher market share, which would hurt the job prospects and earnings of the actors in high-wage settings. These arguments featured in debates on the World Trade Organisation's social clause and were also raised in the discussions that preceded the conclusion of the North American Free Trade Agreement and the EU's enlargement to the south and to the east.

However, to regard low-income countries' wages and social standards as 'an illegitimate export subsidy and a form of social dumping' (van Roozendaal 2002, p. 170) is problematic for at least three reasons. First, the label 'cheaper and thus more competitive' is often applied on the basis of comparisons of raw wages and GDP per capita without taking into account productivity gaps between high- and low-standard settings. In reality, productivity tends to be lower in the latter case, which often compensates for real-wage differentials (de la Dehesa 2007). Second, such claims disregard the fact that social dumping practices are not pursued exclusively by actors from low-wage environments. In particular, the role of high-wage country companies in exploiting the differences in socioeconomic conditions between domestic and foreign locations is rarely a subject of public debate. Third, the choice of highwage country standards as the point of reference in international comparisons is a normative decision that can give a protectionist flavour to accusations of social dumping (Bhagwati 1995).

An analysis of the scientific contributions that have taken on the task of conceptualizing social dumping also reveals a number of problems. Some definitions follow the popular understanding of lower wages and inferior employment standards as being equivalent to social dumping and 'unfair' competition. For instance, the 2012 edition of the European Industrial Relations Dictionary compiled by the European Foundation for the

2. This section builds on a detailed discussion of the uses of the term 'social dumping' in Bernaciak (2012). 
Improvement of Living and Working Conditions (Eurofound) defined social dumping as 'a practice involving the export of goods from a country with weak or poorly enforced labour standards, where the exporter's costs are artificially lower than its competitors in countries with higher standards, hence representing an unfair advantage in international trade' (Eurofound 2012). ${ }^{3}$ According to this definition, virtually all developing countries' exports would fall into the social dumping category. In addition, it is unclear on what basis one can label the price of developing country exports as being 'artificially' low. Just like the participants in the public discourse, Eurofound seems to implicitly refer to the standards of developed/high-wage countries. As pointed out above, however, the decision to adopt the latter's standards as the benchmark is an arbitrary, normative choice.

Other studies consider states as 'social dumpers' using counterfactuals that, by definition, cannot be verified or supported by empirical evidence. Alber and Standing's (2000, p. 99) analysis of global trends in social protection and welfare spending conceptualizes social dumping as 'situations in which standards in one country are lowered relative to what they would have been because of external pressure from all or part of the global economic system'. The authors further specify that the decline can take the form of erosion of the existing levels of social protection or the so-called arrested development of social regulation, which refers to situations where social standards do not advance at a pace proportional to economic growth as a result of external competitive pressures. The notion of arrested development of social policies is problematic, however, because it is difficult to determine what the exact level of social standards would be had it not been for the alleged activity of social dumping. Moreover, the authors seem to impose a universal benchmark for social protection that should be reached by countries at a certain level of development, which is hardly justifiable in view of the considerable variation among developed countries in terms of the degree of social protection they offer. Similar objections can be formulated in relation to Sinn (2003, p. 3), who defines social dumping as the practice by less developed states of 'maintaining an underdeveloped welfare state to create a competitive cost advantage for their industries'. Again, it is unclear what 'underdeveloped' welfare state means exactly. In addition, similar to the popular understandings of the notion, Sinn's focus on the actions of poorer countries' governments ignores the possibility that social dumping initiatives can also be pursued by actors in high-wage environments.

Yet other authors construct their definitions of social dumping in an inductive manner, listing risks related to the notion with regard to a concrete politicaleconomic setting. Discussing the EU Internal Market, for instance, Pochet (1990) warns against social dumping in the form of 1) production relocations; 2) fragmentation of national regulatory environments as a result of intraEU labour mobility; 3) state reforms increasing labour market flexibility

3. Eurofound has recently withdrawn this definition from its dictionary and replaced it with a review of popular and academic uses of the term. 
that are designed to boost a country's competitiveness; and 4) multinational companies' pressures for further flexibilization of employment conditions. Similarly, Mosley (1995) argues that social dumping in the EU may involve 1) the displacement of high-wage country producers by their competitors from low-standard countries; 2) company relocations; and 3) states' low-wage and anti-union policies. Both accounts are interesting in that they point to possible manifestations of social dumping in different policy fields. At the same time, neither can be regarded as a comprehensive catalogue of dumping threats. Because they fail to identify the mechanism underlying the dumping behaviour, they are of relatively little use outside the specific contexts to which they refer.

An important contribution to the scholarly debate on social dumping is Vaughan-Whitehead's (2003) study on the potential impact of EU eastern enlargement on Western European labour markets and social protection systems, which links the issue of social dumping to its counterpart in trade. The author claims that trade dumping and social dumping share a common goal, given that they are both pursued in order to gain a higher market share on the basis of lower prices. The author subsequently defines social dumping as 'any practice pursued by an enterprise that deliberately violates or circumvents legislation in the social field or takes advantage of differentials in practice and/or legislation in the social field in order to gain an economic advantage, notably in terms of competitiveness, the state also playing a determinant role in this process' (Vaughan-Whitehead 2003, p. 325). Vaughan-Whitehead's definition is supplemented by a set of criteria that help determine a company's degree of intention in violating social norms. A significant gap between home- and host-country legislation, for instance, allegedly proves a firm's willingness to enhance its competitive position by investing in the lowstandard environment. Similarly, if the economic condition of an enterprise enables it 'to progressively assimilate working conditions in the host country to those prevailing in the home country', but the firm nevertheless pays its foreign workers wages that are 'well below what is the norm at home', its social dumping motivation is evident (Vaughan-Whitehead 2003, pp. 327 and 326). Vaughan-Whitehead's conceptualization is interesting because it goes further than any other definition in outlining the possible motivation behind social dumping and in specifying the actions it may entail. Nonetheless, it is still ambiguous about the role of governments and does not address the issue of employee involvement in dumping practices. On closer scrutiny, the two criteria put forward by the author are also problematic. According to the first, all foreign direct investment flows to low-wage countries could be viewed as 'dumping driven'. Vaughan-Whitehead fails to distinguish between efficiencyand market-seeking investments and neglects to account for the company practice of transferring the majority of labour-intensive operations to workerrich countries and concentrating the higher value-added activities at home, which might enhance a company's competitiveness and, in consequence, benefit both the home- and the host-country units. The second criterion, on the other hand, recalls Eurofound and Alber and Standing's benchmarks: it is impossible to assess how much a firm should pay its employees, or at which point exactly host-country wages are 'well below' those in the home country. 
To conclude, the available scholarly definitions of social dumping suffer from considerable flaws. They either confuse lower wages and inferior employment standards with social dumping and 'unfair' competition, or mix positive and normative elements, arbitrarily designating the social standards of high-wage countries as the universal criteria. Moreover, most studies take the form of single-case studies and focus on a particular regulatory context, which creates the impression that the term is applied to unrelated phenomena. In a bid to avoid normative traps and to bring different manifestations of social dumping under a common analytical umbrella, I construct my definition of social dumping on the basis of recent theoretical literature on the role of regulation in capitalist economies and on current trends in market expansion. I present my concept in the following two sections and subsequently move on to an analysis of recent trends in European integration through the lens of the opportunities and incentives for social dumping that they have provided. 


\section{Competition and regulation in capitalist markets}

In the simplified reading of neoclassical economics embraced by contemporary market libertarians, the market mechanism is considered the most efficient instrument for allocating scarce resources. In line with Adam Smith's 'invisible hand' paradigm, the benevolent effects of free market exchanges and unbridled competition are not limited to those involved in concrete transactions. Insofar as the rivalry between profit-maximizing actors drives innovation and pushes down the prices of goods and services, it benefits consumers, stimulates economic and technological progress, and thus serves wider societal interests. ${ }^{4}$ This seemingly positive feature of the free market is often invoked to justify the laissez-faire approach to economic regulation and policymaking. According to its proponents, any form of intrusion into free market operations is harmful because it skews the self-regulatory potential of the system, leading not only to reduced economic performance but also to suboptimal aggregate outcomes.

Arrow and Debreu's general equilibrium model demonstrated that the neoclassical notion of benevolent markets rests on assumptions that are impossible to find in practice. Since then, the catalogue of recognized market failures (i.e., situations where the pursuit of individual self-interests does not lead to efficient outcomes) has been steadily growing. ${ }^{5}$ However, whereas traditional accounts of market failures have focused on mechanisms that undermine the 'invisible hand' mechanism, recent contributions to the field of economic theory assert that the very logic of market competition might in itself constitute a market failure. Drawing on earlier work by Schelling (1978) and on insights from Darwin's natural selection theory, Frank (2011) observes that human attainment is often assessed not in terms of one's absolute performance but according to how well one fares relative to others. In the case of so-called positional goods, whose value is measured in terms of their relative rather than their absolute consumption, people have an incentive to build up advantages over their rivals. ${ }^{6}$ If left uncontrolled, however, this process can lead to wasteful spending and underinvestment in non-positional

4. It must be noted that Smith himself remained rather sceptical about the notion of the 'invisible hand'. In particular, he did not argue that the pursuit of self-interest always leads to outcomes that are beneficial for society as a whole (Sen 1987; Frank 2011).

5. The four 'textbook' market failures are: asymmetric information, public goods, externalities and natural monopolies. More recently, other problems, such as time-inconsistent preferences and bounded rationality, have also been studied.

6. For a detailed discussion of competition for positional goods and the related social implications, see Hirsch (2005). 
goods. Positional struggles rarely translate into the expansion of the common good and might actually prove harmful to individual and community interests.

Positional competition features in many everyday situations and is also one of the principal mechanisms guiding the behaviour of self-interested market participants. Business success does not depend on the absolute levels of investment or costs incurred by market participants but on their relative performance vis-à-vis their competitors. In an effort to outcompete its rivals, a company may invest excessively in a certain area, far beyond what would be considered optimal if the absolute and not the relative performance mattered. Alternatively, it might cut expenditure in a domain that does not directly affect its market position, down to a level that adversely affects its general performance. The problem is that once a firm makes a move of this kind, it merely gains a temporary advantage over its competitors, who soon follow a similar course. According to Frank, unbridled competition results in 'expenditure cascades' (Frank 2011, p. 61), while in other contexts it leads to a 'race to the bottom' among self-interested market participants. Even though, at the end of the day, the relative position of the competing firms has not changed in terms of market shares, they have all wasted resources that could otherwise have been used in a more productive way, or they have engaged in unnecessary cost-cutting that has not only reduced the efficiency of their own operations but might also have hurt broader societal interests. All in all, then, where positional competition characterizes the bulk of contemporary market interactions, actors' pursuit of individual gain does not translate into a common good. In most instances, the benevolent effects of the 'invisible hand' fail to materialize because it is more the exception than the rule that individual and group interests coincide.

To illustrate the above argument, let us consider a firm that seeks to outcompete its rivals by lowering its expenditure on wages and reducing the quality of its employees' working conditions. Employee compensation is a non-positional good because, at least at face value, a wage scale is an internal company affair that does not influence the company's position relative to its market competitors. By contrast, a company's performance is highly positional: it is subject to financial market discipline and is reflected, for instance, in share prices and the CEO's remuneration. Initially, the cut in employee compensation or a shift towards poorer employment conditions gives the enterprise an advantage, which soon disappears, however, as other firms follow suit and reduce wages and social protections to a comparable level. Moreover, seeing their wage levels drop and working conditions deteriorate, workers may lose their motivation and work less productively, which will impact negatively on the company's business results. Furthermore, as a result of the reduced income, employees' purchasing power may decline and translate into lower levels of demand. At the end of the day, it might turn out that nobody benefits from the 'race to the bottom': while the relative positions or market shares of the companies implementing the cuts are similar to their values at the outset, they might be suffering from decreasing sales and plummeting corporate profits. The social and economic implications of the salary slash may be even broader and involve deteriorating living standards and lower levels of economic growth. 
It would undoubtedly be in the interest of market participants not to engage in wasteful rivalries of this kind. However, none of them has an incentive to unilaterally change his/her behaviour and withdraw from the race because they would lose out vis-à-vis those competitors who nevertheless decide to increase (or reduce) their spending in order to improve their relative position, irrespective of the negative consequences. Unfettered competition can therefore be a destructive force - a specific form of market failure. It creates collective-action problems that may threaten economic efficiency and longterm market sustainability and hinder the provision of public goods.

How can the negative effects of positional competition be eliminated or at least reduced? This cannot be achieved by relying on the self-regulating market, which, far from offering a solution, is actually the very source of the problem. Instead, competition-driven collective-action problems similar to those described above can be solved by means of market regulation. Welldesigned rules prohibit harmful activities or remove the incentives that encourage individual actors to participate in wasteful spending. Health and safety regulations are a case in point: by setting standards for employee protection, they prevent companies from endlessly reducing their spending on safety measures - a non-positional variable that would otherwise be a likely target of cost-cutting schemes. Moreover, thanks to their universal character, they induce a change in the behaviour of market participants that would not be initiated through individual actions.

Beyond the effects of positional competition, regulation is also used to correct other failures associated with the unfettered functioning of markets. It makes up for informational asymmetries and the resulting lack of trust and thus encourages actors to enter long-term contractual arrangements. It also prevents the abuse of market power by limiting the scope for predatory and rent-seeking behaviour, and protects the state and other non-market institutions from being captured by particularistic interests (Bruszt 2002). Importantly, the rules governing markets are not limited to written laws and statutes, rather also encompass informal codes of conduct and 'ways of doing things' that structure and guide the behaviour of actors in a given politicaleconomic setting. These rules may also be enshrined in the procedures that govern the collective bargaining process, or take concrete shape through the deliberations of the social partners. All of these formal and implicit norms provide a framework within which private market relations - contractual exchanges between self-interested actors - take place (Streeck 2010). Rather than being shaped by pure market forces, then, well-functioning markets are actually constructed. Not only their long-term efficiency, but also their very existence depends on the presence of rules that establish rights and enforce obligations enabling market participants to maximize their profits in a predictable, ordered and closely supervised environment. 


\section{Social constraints and the appeal of social dumping}

Social regulations constitute an important element of the construction of capitalist markets. As observed by Polanyi (2001, p. 75), people are not commodities in the same sense as goods: even though a worker's work in the capitalist system has its market price referred to as 'wage', labour constitutes a field of activity that has 'not [been originally] produced for sale'. For this reason, human beings cannot be fully subject to market forces; the extension of market principles into all areas of societal life would destroy the very substance of society. In order to prevent the devastating effects of universal commodification, society needs to retain the ability to limit the exposure of its members to untamed market mechanisms. To use the term coined by Polanyi, it has to embed the market by subjecting it to a system of regulatory checks and controls. At the same time, society also needs to preserve those institutions governed by non-market logic that assist the weaker or more vulnerable members of the community and decrease their dependence on the market as the principal provider of goods and services. In practice, market embeddedness may take different forms, and its extent varies across specific political-economic settings. Most measures, however, fall within one of the three categories identified by Polanyi: 'factory laws', workers' representation structures and social legislation. Labour laws and industrial relations institutions protect employees from abuse and exploitation, enabling them to defend their interests and to co-shape market and corporate governance processes. Social and welfare policies, on the other hand, are based on the principle of redistribution and 'decommodify' certain members of the community, allowing them to maintain decent living standards by relying (fully or partially) on non-market income sources and provisions (Esping-Andersen 1990).

It is not only society that has to be protected from excessive exposure to 'bare' market forces, however. Social controls and bridles are indispensable for ensuring the undisturbed operation of capitalist markets. This is because, as argued during my earlier discussion of Frank's (2011) volume, competition often tends to channel actors' behaviour into inefficient or wasteful activities. The wide spread of such practices would not only undermine the viability of individual business ventures, but could also lead to the decline, or even the disintegration, of the economic system as a whole. From this perspective, welfare policies cushioning the effects of market forces, as well as regulations preventing or discouraging actors from undertaking socially harmful activities, can be viewed as market-sustaining devices. As argued by Streeck (1997), social restrictions on self-interested rationality may even go beyond this protective function and enhance firms' economic performance. 
Employment protection and minimum-wage regulations may seem restrictive because they prevent companies from cutting wages below a certain level and from 'hiring and firing' as they see fit but, at the same time, they encourage long-term planning and continuous investment in human capital. Similarly, collective bargaining and codetermination rules limit managerial autonomy but they also help build trust between management and workers, boost a sense of responsibility for company performance among employees and stimulate productivity increases. Over time, social constraints might lead to the redefinition of corporate identity, inducing a shift from low-cost to high-quality, capital-intensive production. In this new market segment, a highly motivated, skilled workforce and an ability to innovate constitute key competitive advantages, and thus what used to be viewed as 'constraints [...] can open up as yet unknown [business] opportunities' (Streeck 1997, p. 203). Certain welfare institutions can similarly serve as a 'productive factor' (Ferrera et al. 2001) by contributing to social cohesion and leading to a more efficient utilization of human capital. Universal social security schemes, for instance, create an expectation of temporary relief in the event of job and income loss, stimulating more efficient job-skill matches and benefiting both the jobseeker and the economy.

Despite their beneficial aggregate effects and positive long-term impact, however, the arrangements set up to protect society from the adverse effects of unbridled competition clash with capitalist markets' tendency to expand and subsume those elements of societal activity that do not operate in line with their logic. This process of market expansion, or marketization, can be defined as the introduction or intensification of price-based competition in areas that used to be sheltered from market pressures (Greer and Doellgast 2013). It might involve the spread of markets and their self-regulating logic into new geographical regions or new fields of activity, or the increasing depth of commodification, resulting from the growing exposure of societal actors to the market mechanism (Streeck 2010).

In the academic literature, the recent phase of market expansion is viewed as the result of policy decisions at the national and supranational level inspired by the neoliberal ideology (see van Apeldoorn and Horn 2007; Standing 2009; Crouch 2013). It must be remembered, however, that marketization is not synonymous with deregulation, which is the dismantling of regulations and institutions orchestrated and implemented by policymakers. As argued by Greer and Doellgast (2013, p. 2), marketization is 'institutionally thick' in the sense that alongside the gradual elimination of legal and institutional barriers to the market, it involves the creation of a brand new set of bodies that, unlike the protective institutions in the Polanyian tradition, are geared towards supporting the market-based logic of exchanges. Against this background, the authors identify major directions of the current wave of marketization. The increase of contractual, price-based relations and the creation of internal markets of goods and services within what previously used to be a single organization or company both signify the growing spread of markets. Marketization unfolds through the disintegration of corporate value chains, the privatization of public assets, the practice of outsourcing and the creation 
of semi-independent subsidiaries; it can take place not only within a single economy but also at the cross-border level via foreign direct investments and international trade in goods and services. As markets expand and actors who are external to the company's core become asset holders, subcontractors and suppliers, price mechanisms and uniform criteria for quality and expenditure calculation are adopted to ensure smooth business operations. The resulting standardization of goods, services and production processes enables performance comparisons between individual establishments or service providers, stimulating rivalry within the value chain. By contrast, the increasing reliance on active labour market policies (ALMPs) testifies to the increasing depth of the market and to the growing exposure of society to market mechanisms. By imposing stricter conditions for benefit distribution, ALMPs seek to steer the unemployed back into the market. Moreover, much as they aim at increasing jobseekers' employability, they often lead to their commodification at the lower end of the wage scale. Finally, the liberalization of labour migration regimes in combination with policies promoting crossborder labour mobility simultaneously extends and deepens international markets for labour. As previously sheltered national labour markets are opened up to new entrants, job competition intensifies, affecting not only demographic and employment structures, but also the prices and wage levels in a given political-economic setting.

The above examples suggest that market expansion proceeds not only in a 'top-down' fashion through deregulation drives and the establishment of market-enabling institutions, but also follows directly from the strategic choices of self-interested market participants. Since the beneficial effects of regulatory constraints materialize only in the long term, rational actors forced to act according to the short-term market logic will view them as barriers to profit maximization. In a similar vein, despite the positive aggregate impact of regulation, from the point of view of a profit-maximizing individual it would nevertheless be optimal if he/she could undercut or evade the existing norms at the same time as his/her rivals are abiding by them. As argued by Frank (2011), market actors will primarily be interested in improving their position vis-à-vis their competitors and, in the course of this rivalry, they are likely to sacrifice non-positional goods such as wages and working conditions. As a result, instead of internalizing social norms and constraints imposed on the market, individual market participants will have an incentive to ignore them or to adjust them to serve their needs. In the words of Streeck (2010, pp. 15 and 21), 'a typical rule taker' might be rewarded with a higher profit or a larger market share 'for undercutting public or private regulatory institutions'.

It is in the context of actors' pressures on the regulatory framework that the notion of social dumping comes into play. I view social dumping as a specific subcategory of marketization - market actors' rebellion against social norms and obligations that may negatively affect their profit margins and market position in the short term. I accordingly define social dumping as the practice, undertaken by self-interested market participants, of undermining or evading existing social regulations with the aim of gaining a short-term advantage over their competitors. 
The actor-driven social dumping and 'top-down' marketization initiatives discussed earlier in this section do not take place in isolation, rather are mutually reinforcing. The spread of certain forms of social dumping may induce legislative changes that depenalize or even encourage such practices, or may prompt the creation of institutions ensuring the further expansion of the market mechanism at the cost of social regulation. This might also have an impact on social conventions and those elements of the regulatory structure that are not formally enshrined in law: by affecting the societal perception of what constitutes a social norm, the spread of social dumping might lead to societal approval (or, conversely, a more categorical rejection) of a given behavioural pattern. On the other hand, social dumping practices are encouraged by national and supranational initiatives to expand markets. Insofar as deregulation and the establishment of market-making institutions expose previously sheltered actors to competition, or increase their exposure to competitive pressures, they provide them with incentives to disregard or contest the social constraints that still remain binding for their rivals. In the next section, I apply this logic to the process of EU economic integration and demonstrate how the excessive focus on market-expanding measures in Europe has encouraged market actors to engage in social dumping. 


\section{Europe: from social model to social dumping?}

In the first three decades after World War Two, the countries of Western Europe countries developed at an unprecedented speed. Alongside high levels of economic growth and substantial productivity increases, the post-war 'miracle' brought about a spectacular rise in living standards across all societal groups (Boyer and Hollingsworth 1997). The speedy recovery and the balanced economic expansion that followed were by no means accidental, however. They relied on rules and institutions put in place by European governments to contain market forces and to channel the behaviour of individual market actors for socially desirable outcomes. Together with basic social laws enacted at the level of the European Economic Community (EEC), this set of values, norms and policy instruments constituted a uniquely European approach to socioeconomic policymaking or, to use the term popularized by the former President of the European Commission Jacques Delors, added up to the 'European Social Model' (Jepsen and Serrano Pascual 2005, p. 234). According to Ferrera et al. (2001), its common features encompassed basic universal social security systems, collective bargaining institutions and structures for the representation of socioeconomic interests, as well as high levels of income equality. In a similar vein, Vaughan-Whitehead (2003) identified substantial elements of the 'model', which included labour law and public services; policy principles guiding its creation, such as nondiscrimination and equal opportunities; and various forms of social activism that it stimulated, in particular social dialogue, collective bargaining, and civil society's involvement in the policymaking process.

To be sure, the existence of common traits by no means implied that national varieties of regulatory systems ceased to exist. European countries continued to exhibit considerable variation with regard to their welfare and industrial relations institutions, the extent of social protection provided, and the degree of institutionalization of specific governance instruments (see, e.g., EspingAndersen 1990; Hall and Soskice 2001; Huber and Stephens 2001). These differences could be traced back to institutional legacies, national values and power relations between major socioeconomic and political groups (Ebbinghaus 1999). Nor did it mean that the national systems, once established, remained intact; on the contrary, they were constantly evolving as a result of internal deliberation and external pressures (see, e.g., Pierson 2001; Streeck and Thelen 2005). What is important, however, was the shared logic behind the post-war social systems. By embracing the European Social Model, Western European governments had committed themselves to protecting their citizens from the negative effects of exposure to market forces by providing them with social 
safety nets and non-market-based income sources. At the same time, they had given organized interest groups an opportunity to co-shape the course of social and economic policies, creating space for necessary market corrections and interventions for the sake of the common good. The effect of this regulatory effort was a two-track policy course combining the goal of economic efficiency with that of social cohesion, which distinguished Europe from other developed parts of the world. While the US and East Asian countries exhibited equally impressive levels of economic growth, Western Europe fared much better in terms of equality and social justice (Vobruba 2001).

Over time, however, the balance between market expansion and social protection began to change. The first cracks in the European Social Model appeared in the early 1970s. Following the oil crisis, economic growth in most Western European countries slowed down or stalled completely. In an effort to bring down rapidly growing unemployment figures, governments resorted to new policy remedies inspired by the neoliberal ideology. At the same time, increased competition from other regions of the world, in particular from the US and the expanding East Asian economies, forced European leaders to seek new ways of raising economic efficiency and forging growth opportunities for domestic businesses. To an extent, the solutions adopted to tackle the economic stagnation and external pressures remained country specific and mirrored the existing differences in the countries' institutional set-ups and political-economic interest constellations. The general trend, however, was that of an increased reliance on markets and a growing belief in their efficiency-enhancing impact. These ideas have also made their way to the supranational level and thus influenced the two major European integration projects implemented since the 1980 o - the launch of the EU Internal Market and enlargement of the EEC (EU) to the south and to the east.

\section{The EU Internal Market: liberalization and regulatory stalemate}

The creation of the Internal Market featured in the Treaty of Rome as one of the goals of the EEC. In a nutshell, it entailed the gradual consolidation of EEC member states' markets into a common market space. By allowing goods, capital, labour and services to move freely across national boundaries, the Internal Market was expected to boost international trade and investment, enabling companies to benefit from increased specialization, higher economies of scale, and foreign demand. The first step in this direction was the elimination of tariffs and quantitative restrictions on intra-EEC trade, followed by the establishment of customs union among the member states in 1968. The process gained new momentum in the 1980s, not least due to vigorous lobbying by international business representatives (van Apeldoorn 2002). The Single European Act signed in 1986 set 1992 as the provisional deadline for the completion of the Internal Market process. The integration of European service markets advanced at a slower pace, with two landmark acts - the Posted Workers Directive (PWD) and the Services Directive - being introduced in 1996 and 2006, respectively. 
The process of building a unified European market space has been a large-scale exercise in marketizing. It has involved the removal of constraints on crossborder business operations and the introduction of the market mechanism in domains that had traditionally been sheltered from competitive pressures, such as utilities and certain public services (Clifton et al. 2003; Keune et al. 2008). The speed and vigour of the Europe-wide liberalization drive, however, has not been matched by the development of joint norms and regulations aimed at protecting market actors and society from excessive exposure to competition. As argued by Scharpf (1996), this has largely been a result of the EEC's institutional set-up. The two institutions charged with furthering the Internal Market agenda - the European Commission and the European Court of Justice (ECJ) - have a supranational character and are not subject to the control of national constituencies. As a consequence, they were able to act relatively promptly and to pursue the Internal Market agenda 'without much political attention' (Scharpf 1996, p. 15). The principle of supremacy of EU law over national legislation, enshrined in the Rome Treaty and subsequently confirmed by the ECJ's rulings, legitimized their market-making efforts. It has only been in the context of recent ECJ decisions that explicitly put economic freedom before fundamental social rights that the wide scope of their mandate and the lack of democratic accountability have come under criticism (Blanke 2008; Höpner 2012). In contrast, joint social regulations at the Community level needed to be based on a compromise within the intergovernmental Council of Ministers. Such agreement was difficult to reach, however, because cross-national differences in factor prices and factor productivity translated into diverging preferences with regard to the extent of social protection that should be provided. Countries adhering to lower standards feared losing their competitive advantage and thus preferred to abstain from joint regulation or to set European standards as low as possible. At the opposite end of the spectrum, states characterized by high levels of social protection were reluctant to accept the logic of 'lowest common denominator', fearing the subsequent pressure on standards in their own jurisdictions. The resulting stalemate was sometimes solved by means of compensation (e.g., in the form of social funds) offered by richer countries to the poorer ones in exchange for the latter's acceptance of a more stringent Community regulation (Leibfried and Pierson 1995). More often than not, however, conflicting preferences within the Council precluded the development of joint social rules, resulting in a 'fundamental asymmetry' between negative and positive integration in Europe (Scharpf 1996, p. 15; also see Crouch 2013) and the reduction of the Internal Market's raison d'être to its liberalizing function.

Neither could the expansion of the European market be counterbalanced by protective social regulations at the national level. As argued by Pelkmans (2012), the Internal Market regime guaranteed actors unconditional access to other member states' markets and thus went beyond the provisions of standard agreements on trade liberalization. Potential restrictions on these freedoms needed to be well grounded and applied only in strictly defined situations. But even if regulatory interventions were allowed, European governments would have little incentive to impose more stringent rules. Once the scope of the market ceased to overlap with state boundaries, any attempt 
at the national level to introduce additional restrictions or to enact regulations stricter than those in other EU countries could result in capital flight and the shift of productive activities towards other, more permissive environments. In this respect, the creation of a Europe-wide market space has not only limited EU member states' regulatory capacity but has also opened the door to 'regime shopping' and a 'race to the bottom' in relation to market, social and environmental norms (Leibfried and Pierson 1995; Scharpf 1996).

\section{EU enlargement: diversity and growing competitive pressures}

Tensions between social regulations and the market-making agenda became particularly pronounced with the extension of the European market to the Southern (in the 1980s) and the Central-Eastern European (CEE) countries (in the 2000s). From the point of view of high politics, the rationale for the two enlargement rounds was never called into question. The former round was viewed as a major factor in stabilizing the three newly democratized Mediterranean regimes; it also had geopolitical importance in that it expanded the Western European capitalist camp (Wallace 1979; Verney 2006). Similarly, EU eastern enlargement was regarded as an important step towards the reunification of the continent, marking the CEE states' 'return to Europe' after several decades of the East-West divide. In both instances, however, economic disparities between 'old' EEC/EU member states and the newcomers became a matter of concern. In a report issued in the 1960s, the European Commission still referred to Greece as a country 'in the course of development' (quoted in Siotis 1981). In 1975, Spain's GDP per capita was $71 \%$, and Portugal's only $49 \%$ of the EU average (ETUI 1979). ${ }^{7}$ In the early 2000s, the East-West gap was even wider, with CEE candidate countries' GDP per capita amounting to only $45 \%$ of the EU average (Krings 2009). As regards earnings, gross annual wages across the post-communist region remained far below EU15 standards: in 1999, Slovenia arrived at $71 \%$ and Bulgaria at only $22 \%$ of the EU average (Kunz 2002). The statistical differences were supplemented by qualitative reports pointing to the fragility of tripartite structures in CEE, politicized industrial relations systems, and half-hearted adoption of the already meagre EU social acquis (Keune 2008; Meardi 2012).

The post-enlargement European market offered fertile ground for the evasion of social regulations. With regard to cross-border service provision, Greek, Portuguese and Spanish firms initially posted their workers on the territories of other member states and paid them in line with their home-country rates. In view of concerns over low-wage competition, the ECJ ruled, in the 1990 Rush Portuguesa case, that EEC member states could extend certain (and potentially even all) employment regulations to posted workers. However, the focus on basic rules later established by the PWD and subsequent ECJ rulings made it possible for companies to exploit the difference between minimum and standard levels of protection. Combined with weak enforcement, the

7. All figures at purchasing power parity. 
minimum-protection approach has made employee posting particularly prone to social dumping. In manufacturing sectors, the extended Internal Market has enabled companies to move production to cheaper or less regulated locations in Southern and, later on, Central-Eastern Europe, or to use the threat of exit to extract concessions from employees in more stringent regulatory settings. Large multinational companies have also found it easier to play off national governments against one another, making investments conditional on generous subsidies and labour market reforms, which has sometimes led to regulatory 'races to the bottom' (Bohle 2008). Finally, the prospect of labour migration from new, low-wage EU member states has increasingly become an object of concern. In the aftermath of both southern and eastern enlargement, most 'old' member states temporarily imposed labour market restrictions. While the transition periods admittedly reduced migratory inflows into certain jurisdictions, they also encouraged bogus selfemployment that often amounted to social dumping (Galgòczi et al. 2012). Migrants have often worked for less than domestic employees in the host countries, which has enabled their employers to cut costs spent on wages and social contributions. Moreover, the growing pool of foreign workers has decreased companies' dependence on local workforces, putting pressure on wages and working conditions in the host countries.

Scharpf's (1996) account of regulatory traps in the context of the heterogeneous Internal Market can be applied both to the southern and the eastern EU enlargement rounds. In the context of debates on the PWD in the early 1990s, the divide between Northern European countries (pushing for a wide catalogue of social standards applicable to posted workers and shorter grace periods during which posted companies could still apply home-country regulations) and Southern European and Anglophone states (demanding less stringent regulations) was particularly apparent (Eichhorst 1998). Following EU eastern enlargement, CEE governments became vocal defenders of EU economic freedom. They supported the original Commission proposal for the EU Services Directive and the so-called country-of-origin principle, which stipulated that an individual or a company was allowed to provide services on the territory of another EU member state on the basis of the laws and regulations of his/her country of origin or the country of establishment of the business, and not those of the host state (Gajewska 2009). Even though the final version of the Directive did not follow the country-of-origin logic, the discord continued. In written observations submitted to the ECJ in the context of the Laval and Viking cases, CEE governments, together with the UK and Ireland, advocated the primacy of economic rights over social protection - at a time when the remaining EU member states were arguing the opposite (Lindstrom 2010). More recently, the majority of CEE countries suggested that only a limited catalogue of national control measures be included in the planned PWD Enforcement Directive. These examples point to the existence of deep political cleavages in the enlarged EU and dash hopes for a more balanced development of social and market-making regulation in the foreseeable future. Particularly with respect to the EU eastern enlargement, then, one can speak of a double-negative effect: the process has simultaneously 'exacerbate[d] the scope and nature of regime competition within Europe's integrated market, 
and threaten[ed] to stall further Europeanisation of the institutions and processes of labour market regulation' (Marginson 2006, p. 12).

By focusing more closely on the EU Internal Market and EEC (EU) enlargement, I did not wish to claim that social dumping has been unique to these two processes. As shown by Frank (2011), the very logic of competition provides market participants with powerful incentives to avoid or circumvent regulatory constraints, including social regulations. Tensions between the existing constraints and the possible short-term benefits of evading them are inherent in the capitalist system of production and accumulation; as a result, social dumping is practised by different groups of actors in a variety of market settings. In the European context, however, these two instances of 'top-down' marketization inspired by the neoliberal paradigm have been particularly relevant. They have simultaneously extended both the scope and the depth of the European market, leading to the unprecedented intensification of price-based competition. In effect, not only have they made micro-level rule evasion more prevalent, they have also provided market participants with new strategic opportunities to contest or 'bend' the existing social constraints. As the threat of social dumping has become more imminent, it has grown into one of the most pressing political and social concerns in Europe. It has also emerged as an important topic of popular and policy debates. 


\section{Conclusion}

In the political-economic literature, the recent phase of market expansion is usually viewed as a top-down process: the result of liberalization and deregulation policies pursued at the supranational and national levels. In this paper I argued, however, that marketization is not an exclusive domain of policymakers. Forced to act according to short-term market logic, selfinterested market participants have an incentive to circumvent or 'bend' existing social regulations, viewing them, as they do, as barriers to profit maximization. In so doing, they set in motion a bottom-up marketization process and expand the sphere governed exclusively by market forces. It is this practice of undermining or evading social norms and regulations, undertaken with the aim of gaining a competitive advantage, that I conceptualized as social dumping.

At the same time, I claimed that social dumping and top-down marketization initiatives did not take place in isolation and that actors' efforts to undercut social regulations were encouraged by policy initiatives to expand markets. Focusing on the European context, I showed how two major EU integration projects - the launch of the EU Internal Market, and EU enlargement to the south and to the east - had led to the intensification of price-based competition, providing market participants with new incentives and strategic opportunities to undermine and avoid social norms.

The conceptualization proposed in the paper goes against four common presumptions about social dumping found in the European public discourse and in recent academic studies on the topic. First, it asserts that social dumping is not limited to cross-border labour mobility and employee posting. Following EU enlargement to the south and the east, the term has indeed been used mainly in relation to pressure on wages and working conditions made possible, or facilitated, by intra-EU labour migration and service provision. But the focus on the mechanism behind the notion - rather than on its most easily identifiable manifestations - suggests that social dumping practices have been equally widespread in other segments of the market. In manufacturing sectors, for instance, rule avoidance has often been the main motive behind production relocations and concession bargaining; it has also been characteristic for certain outsourcing practices and measures intended to increase labour market flexibility.

Second, in line with the conceptualization developed in this paper, social dumping is not an exclusive domain of actors coming from new EU member 
states or, more generally, low-wage countries. While cross-border differences in wage rates and levels of social protection give market participants an incentive to evade stricter regulations, the popular view of low-wage country actors as those 'dumping' on their richer counterparts does not paint the full picture. For one, multinational companies originating from and/or headquartered in high-wage countries actively search for ways to avoid regulatory constraints - in high- and low-wage settings alike. High-wage country actors might also indirectly force other market participants into social dumping practices. Large construction companies, for instance, induce social dumping at lower levels of the production chain (often 'populated' by low-wage country firms and migrant workers) by setting exceptionally low prices for their subcontractors. This strategy allows them to keep their own costs down and at the same time to avoid responsibility for rule avoidance.

Third, social dumping should not be viewed solely as a company strategy. In particular, the role of workers in furthering social dumping, albeit controversial and often indirect, should also be taken into account. It is true that in the majority of cases, companies' efforts to undermine or evade the existing social regulations result in employee abuse. On the other hand, workers often participate in the 'race to the bottom': in the case of concession bargaining, for instance, they accept the rules of the game set by the employer and seek to obtain a competitive advantage by compromising on wages and working conditions. In the absence of systematic micro-level evidence, it is difficult to draw a definitive line between workers' exploitation and practices that are in breach of the existing norms but are nevertheless viewed by workers as 'permissible'. Furthermore, it is important to acknowledge the role of states and EU institutions in providing strategic 'windows of opportunity' for social dumping practices. By easing regulatory constraints and introducing market mechanisms to areas previously sheltered from market pressures, these two groups of actors have been instrumental in fostering the current wave of regulatory evasion.

Last, but not least, social dumping does not have to be a transnational phenomenon. Rule evasion and the undercutting of social standards are arguably more widespread in a cross-border context, where the differences between social standards and, as a corollary, possible gains from rule evasion are higher than in the single-country setting. But while the transnational character of business activity is related to the most often evoked and easily detectible manifestations of social dumping, it is neither the necessary nor the sufficient condition for the practice to occur. Inter-plant rivalry and the resulting concession bargaining may involve plants located in one and the same country. By the same token, the internal flexibilization of workforces (i.e., the practice of replacing a permanent workforce with cheaper and more vulnerable temporary and agency workers) may well take place within one country or even within a single establishment.

In terms of the consequences of social dumping practices, in the short term social dumping is likely to exert downward pressure on wages and working conditions. The spread of rule-bending is likely to induce a change in the 
behaviour of previously rule-abiding market participants: when adherence to social and labour standards turns into a competitive disadvantage, such participants will have no choice but to follow suit and compromise on their own compliance. Over a longer period of time, however, if social dumping practices become rampant or even legally sanctioned, the consequences of regulatory evasion might be even more profound. Social dumping may pose a major challenge to social cohesion insofar as it broadens existing gaps and creates new divisions at the company, sectoral and societal level. The dismantling of social regulations will also do away with the beneficial economic effects that such 'constraints' have on company performance. For instance, the deterioration of working conditions and the growing use of whipsawing practices by managements may undermine workers' trust, negatively affecting their motivation and preventing productivity improvements. Worse still, if market regulations are dismantled or become a 'paper tiger' as a result of pervasive rule evasion and/or the lack of efficient enforcement mechanisms, competition might result in market failure. In line with Frank's (2011) argument presented in the first section, this is because in the absence of adequate regulation, market participants tend to focus primarily on boosting their relative performance and investing in positional goods such as their place in the market ranking. Such races could significantly reduce, or even impede, market actors' ability to engage in beneficial market exchanges. Paradoxically, then, the spread of social dumping practices - actions aimed at extending the domain regulated by market forces - may actually lead to the disintegration of the market order.

The long- and short-term threats posed by social dumping call for a resolute policy response. There is a need to curb deregulation and to provide adequate monitoring and enforcement of the existing norms. In certain policy areas where social dumping is most prevalent, such as cross-border employee posting or freedom of establishment, re-regulation and the strengthening of controlling measures is necessary to prevent further abuses, sustain wage levels, employment conditions and worker participation mechanisms, and ensure the undisrupted functioning of markets. Economic regionalization and the intervention of supranational governance structures such as the EU could, in principle, compensate for the loss of state power. By enacting appropriate regulations at the supranational level, they could tame market participants' rule-bending endeavours. In view of the current political climate in Europe, however, it seems that the prospects for a re-regulation of areas prone to social dumping are rather meagre. As shown by the recent debate over the PWD Enforcement Directive and the subsequent legislative compromise, even appropriate enforcement of the existing rules is seen by policymakers and business lobbyists as an undesirable restriction on the EU economic freedoms. However, as long as the neoliberal policy frame guides the direction of EU and national policies, and the emphasis is put on cost-cutting measures that openly encourage cost-based rivalry, social dumping incentives might actually be on the rise. Only the (re-)introduction of effective regulation can prevent, or at least limit, the spread of social dumping practices in Europe. 


\section{References}

Alber J. and Standing G. (2000) Social dumping, catch-up or convergence? Europe in a comparative global context, Journal of European Social Policy, 10 (2), 99-119.

Bernaciak, M. (2012) Social dumping: political catchphrase or a threat of labour standards?, Working Paper 2012/06, Brussels, ETUI.

Bhagwati J. (1995) Trade liberalisation and 'fair trade' demands: addressing the environmental and labour standards issues, The World Economy, 18 (6), 745-759.

Blanke T. (2008) Die Entscheidungen des EuGH in Fällen Laval, Viking und Rueffert - Domestizierung des Streikrechts und europaweite Nivellierung der industriellen Beziehungen, Oldenburger Studien zur Europäisierung und zur transnationalen Regulierung 18/2008.

Bohle D. (2008) Race to the bottom? Comparative institutional advantages? Competition of capitalisms in the enlarged EU, Paper presented at the Political Economy Research Group seminar, Central European University, Budapest, 26 March 2008.

Boyer R. and Hollingsworth J.R. (1997) From national embeddedness to spatial and institutional nestedness, in Boyer R. and Hollingsworth J.R. (eds.) Contemporary capitalism: the embeddedness of institutions, Cambridge, Cambridge University Press, 433-484.

Bruszt L. (2002) Market making as state making: constitutional and economic development in post-communist Eastern Europe, Constitutional Political Economy, $13(1), 53-72$.

Clifton J., Comín F. and Díaz Fuentes D. (2003) Privatization in the European Union: public enterprises and integration, Dordrecht, Kluver Academic Publishers.

Crouch C. (2013) Europe and problems of marketization: from Polanyi to Scharpf, Lectio Magistralis 4, Florence, Firenze University Press.

de la Dehesa G. (2007) Are developing countries engaging in 'social dumping'?, http://voxeu.org/index.php?q=node/213.

Ebbinghaus B. (1999) Does a European Social Model exist and can it survive?, in Huemer G., Mesch M. and Traxler F. (eds.) The role of employer associations and labour unions in the EMU, Aldershot, Ashgate, 1-26.

Eichhorst W. (1998) European social policy between national and supranational regulation: posted workers in the framework of liberalized services provision, MPIfC Working Paper 98/6, Köln, Max-Planck-Institut für Gesellschaftsforschung.

Esping-Andersen G. (1990) The three worlds of welfare capitalism, Princeton, Princeton University Press.

ETUC (2013) EU governments must end social dumping - ETUC calls on ministers to enforce posted workers' rights, Press release, 6 December 2013, http://www.etuc. org/press/eu-governments-must-end-social-dumping-etuc-calls-ministers-enforceposted-workers\%E2\%80\%99-rights\#.U8Yht0ri6W8. 
ETUI (1979) Enlargement of the European community following the accession of Greece, Spain, and Portugal: socio-economic aspects, Brussels, European Trade Union Institute.

Eurofound (2012) Social dumping, http://www.eurofound.europa.eu/areas/ industrialrelations/dictionary/definitions/SOCIALDUMPING.htm (version accessed on 16 January 2012).

Ferrera M., Hemerijck A. and Rhodes M. (2001) The future of the 'European Social Model' in the global economy, Journal of Comparative Policy Analysis: Research and Practice, 3 (2), 163-190.

FIEC (2012) Annual Report 2012, http://www.fiec.eu/en/library-619/annual-reportenglish.aspx.

Frank R.H. (2011) The Darwin economy: liberty, competition and the common good, Princeton, Princeton University Press.

Gajewska K. (2009) Transnational labour solidarity: mechanism of commitment to cooperation within the European trade union movement, Abingdon, Routledge.

Galgòczi B., Leschke J. and Watt A. (2012) Labour migration in troubled times: skill mismatch, return and policy responses, Farnham, Ashgate.

Greer I. and Doellgast V. (2013) Marketization, inequality and institutional change, Working Paper WERU5, London, University of Greenwich.

Hall P.A. and Soskice D. (eds.) (2001) Varieties of capitalism: the institutional foundations of comparative advantage, Oxford, Oxford University Press.

Hirsch F. (2005) Social limits to growth, London, Routledge.

Höpner M. (2012) Usurpation statt Delegation. Wie der EuGH die Binnenmarktintegration radikalisiert und warum er politischer Kontrolle bedarf, MPIfG Discussion Paper 08/12, Köln, Max-Planck-Institut für Gesellschaftsforschung.

Huber E. and Stephens J.D. (2001) Development and crisis of the welfare state: parties and policies in global markets, Chicago, University of Chicago Press.

Jepsen M. and Serrano Pascual A. (2005) The European Social Model: an exercise in deconstruction, Journal of European Social Policy, 15 (3), 231-245.

Keune M. (2008) EEU enlargement and social standards: exporting the European Social model?, Working Paper 2008/01, Brussels, ETUI.

Keune M., Leschke J. and Watt A. (2008) Privatization and liberalization of public services in Europe, Brussels, ETUI.

Krings T. (2009) A race to the bottom? Trade unions, EU enlargement and the free movement of labour, European Journal of Industrial Relations, 15 (1), 49-69.

Kunz J. (2002) Labour mobility and EU enlargement: a review of current trends and debates, Discussion Paper 2002.02.01, Brussels, ETUI.

Leibfried S. and Pierson P. (1995) Multitiered institutions and the making of social policy, in Leibfried S. and Pierson P. (eds.) European social policy: between fragmentation and integration, Washington, DC, Brookings Institution, 1-40.

Lindstrom N. (2008) Service liberalization in the enlarged EU: a race to the bottom or the emergence of transnational political conflict?, Journal of Common Market Studies, 48 (5), 1307-1327.

Marginson P. (2006) Between Europeanization and Regime competition: labour market regulation following EU enlargement, Warwick Papers in Industrial Relations 79, Coventry, IRRU, University of Warwick.

Meardi G. (2012) Social failures of EU enlargement: a case of workers voting with their feet, New York, Routledge. 
Mosley H. (1995) The 'social dumping' threat of European integration: a critique, in Unger B. and van Waarden F. (eds.) Convergence or diversity? Internationalization and economic policy response, Aldershot, Avebury, 182-199.

Pelkmans J. (2012) Mutual recognition: economic and regulatory logic in goods and services, Bruges European Economic Research Papers 24/2012, Brugge, College of Europe.

Pierson P. (ed.) (2001) The new politics of welfare state, Oxford, Oxford University Press. Pochet P. (1990) Dumping social: un concept operationnel?, Nota Bene, 56, 1-4.

Polanyi K. (2001) The great transformation: the political and economic origins of our time, $2^{\text {nd }}$ ed., Boston, Beacon Press.

Scharpf F.W. (1996) Negative and positive integration in the political economy of European welfare states, in Marks G. et al. (eds.) Governance in the European Union, London, Sage, 15-39.

Schelling T.C. (1978) Hockey helmets, daylight savings and other binary choices, in Schelling T.C., Micromotives and macrobehavior, London, W.W. Norton, 211-244.

Sen A. (1987) On ethics and economics, Oxford, Basil Blackwell.

Sinn H.-W. (2003) Social dumping in the transformation process?, NBER Working Paper 8364, Cambridge, MA, National Bureau of Economic Research.

Siotis J. (1981) The politics of Greek accession, in Minet G., Siotis J. and Tsakaloyanis P. (eds.) The Mediterranean challenge. 6, Spain, Greece and Community politics, Sussex European Papers 11/1981, Brighton, University of Sussex, 85-120.

Standing G. (2009) Work after globalization: building occupational citizenship, Cheltenham, Edward Elgar.

Streeck W. (1997) Beneficial constraints: on the economic limits of rational voluntarism, in Boyer R. and Hollingsworth J.R. (eds.) Contemporary capitalism: the embeddedness of institutions, Cambridge, Cambridge University Press, 197-221.

Streeck W. (2010) Taking capitalism seriously: toward and institutionalist approach to contemporary political economy, MPIfG Working Paper 10/15, Köln, Max-PlanckInstitut für Gesellschaftsforschung.

Streeck W. and Thelen K. (eds.) (2005) Beyond continuity: institutional change in advanced political economies, Oxford, Oxford University Press.

Vaughan-Whitehead D. (2003) EU Enlargement versus social Europe? The uncertain future of the European Social Model, Cheltenham, Edward Elgar.

van Apeldoorn B. (2002) Transnational capitalism and the struggle over European integration, London, Routledge.

van Apeldoorn B. and Horn L. (2007) The marketisation of European corporate control: a critical political economy perspective, New Political Economy, 12 (2), 211-235.

van Roozendaal G. (2002) Trade unions and global governance: the debate on a social clause, London, Continuum.

Verney S. (2006) Justifying the second enlargement: promoting interests, consolidating democracy or returning to the roots?, in Sjursen H. (ed.) Questioning EU enlargement: Europe in search of identity, London, Routledge, 20-44.

Vobruba G. (2001) Coping with drastic social change: Europe and the US in comparison, in Beck W. et al. (eds.) Social quality: a vision for Europe, The Hague, Kluwer Law International, 251-270.

Wallace W. (1979) Grand gestures and second thoughts: the response of member countries to Greece's application, in Tsoulakis L. (ed.) Greece and the European Community, Farnborough, Saxon House, 21-38. 